\title{
Impact of Prevailing HRM Practices on Job Satisfaction: A Comparative Study of Public and Private Higher Educational Institutions in India
}

\author{
Sayeeduzzafar Qazi ${ }^{1} \&$ Vikram Jeet ${ }^{2}$ \\ ${ }^{1}$ College of Business Administration, University of Business \& Technology, Jeddah, KSA \\ ${ }^{2}$ College of Business Administration, IHGI, Punjab Technical University, Jalandhar, India \\ Correspondence: Sayeeduzzafar Qazi, Professor, College of Business Administration, University of Business \& \\ Technology, Jeddah, KSA. E-mail: sayeed@ubt.edu.sa
}

Received: October 18, 2016

Accepted: November 21, 2016 Online Published: December 28, 2016

doi:10.5539/ijbm.v12n1p178

URL: http://dx.doi.org/10.5539/ijbm.v12n1p178

\begin{abstract}
A sound HRM system can be generated through the effective HRM practices. HRM practices refer to all activities that are directed towards the management of human resources and the employment of the resources for fulfillment of desired organizational objectives. Job satisfaction "as summation of employees feelings in four important areas namely, job, management, personal adjustment and social relations". The present study was conducted on 526 faculty members randomly drawn of Government and Private affiliated higher educational institutions of India using questionnaire method. The results indicates that faculty member of government higher educational institutes has a moderate level of satisfaction with the overall HRM practices. Employees were more satisfied with training, teamwork and employee participation and satisfied to small extent with performance appraisal and compensations. The study also revealed that there is no significant difference between the government and private educational institution's faculty scores on all HRM practices. A significant positive correlation has been obtained among the job satisfaction with the dimensions of the human resources management in both government and private higher educational institution's faculty members.
\end{abstract}

Keywords: HRM practices, job satisfaction, training \& development, higher educational institutions, performance appraisal, compensation

\section{Introduction}

Growth of the developing countries has been significantly positively correlated with the human capital, where educational institutions play an important role to build capable and educated societies. People of the nation write the success story of any country and education is only the success mantra to make the people ready to face the challenges of upcoming future expectation. In this current era of modernization where technology is challenge for technology itself, it is important to satisfy the needs of our employee to enhance organizational performance. To serve this purpose, organizations are focusing on work related behavior which is more critical for individual as well as organizational success. HRM practices are the approaches by which organization can enhance the job satisfaction among the employees. Present study is an attempt to understand the level of HRM practices and how these practices effect the job satisfaction among the faculty members of the public and private educational institutions.

\subsection{Human Resource Management Practices}

Managing people is much more difficult than managing other resources, where HRM plays a crucial role to bridge organizational and employee's expectations. HRM is composed of the policies, practices, and systems that influence employees' behavior, attitude, and performance. An effective HRM system can be generated through the effectual HRM practices. It refers to all activities that are directed towards the management of human resources and the employment of the resources for fulfillment of desired organizational objectives (Schuler \& Jackson 1987). Koch and McGrath (1996) explored HRM practices to improve employee's commitment, employee's competency and creativity leads towards the attainment of organization objectives. Researchers identify different type of HRM practices in different sectors. Each researcher has their own view to implementation of practices as per the requirement. The applicability of practices depends upon the level of 
employees; organization; industry and the culture. As Pfeffer (1994) initially, identified the following seven practices employment security, selective hiring, self-managed teams/team working, high compensation contingent on organizational performance, extensive training reduction in status difference and sharing information. Further, Redman and Matthews (1998) identify six HRM practices especially to service organizations to support quality strategies, i.e. Recruitment and selection, extensive remuneration systems, team working and flexible job design, training and learning, employee involvement and performance appraisals. Huselid (1995) studied eleven practices that are personnel selection, performance appraisal, incentive compensation, job design, empower of decision, information sharing, attitude assessment, labour management participation, recruitment efforts, employee training and promotion criteria.

\subsection{Training and Development}

According to Flippo, "Training is the act of increasing the knowledge and skills of an employee for doing a particular job". Training involves enhancing and imparting the basic skills that are usually important to perform a specific job in the organization. The basic purpose of training is make employees more productive. It is a formal and systematic process of change in the behavior through learning, resulted from the series of educational programs, instruction modules and planned exercises (Armstrong 2001).

\subsection{Team Work}

A team is a group of people working together towards a common goal. Teams are characterized as "a set of two or more people dynamically, interdependently, and adaptively working towards the achievement of common and valued goal/objective/mission", Salas et al. (1992). Tambe (1997), characterized team behavior as a process of sharing the goals they want to achieve, sharing knowledge, intention to execute the plan, sharing their capabilities and to monitor their own progress towards the team goal. Thus, team can be defined as a group of individual's integrated functioning towards common mission or goal.

\subsection{Performance Appraisal}

According to Flippo, "Performance Appraisal is the systematic, periodic and an impartial rating of an employee's excellence in matters pertaining to his present job and his potential for a better job." Performance Appraisal includes, evaluating the employee's performance in their jobs and comparing it with the standards, and further communicating the feedback to the employees. Armstrong (2001) defined as "a strategic approach to delivering sustained success to organisations by improving the performance of people who work in them and developing the capabilities of teams and individual contributors"

\subsection{Compensation}

Employee compensation is another major HRM practice to improve job satisfaction among the employees of an organization. Compensations policies and motivating reward system of an organization can influence the behavior of the employees and treated as indicators of the organization attitude and concern for employees. Luthans (1998) explain compensation not only to attain basic requirement of the employees, but are also helpful to fulfilling the higher level needs. Once a level of needs achieved next level of needs motivate people to achieve higher level of needs. Therefore compensation is considered as most significant variables for job satisfaction.

\subsection{Employee Participation}

Poole and Jenkins (1997) projected basic principles to achieve superior employee involvement in the organization. Employee participation with the help of work councils, management support to employee participation in work and decision making, trade unions, collective bargaining and to provide equal opportunities for employees to present views on development initiatives and other major issues. Employee participation improves the understanding of the objective of the organization and the strategies to achieve efficiently. Meyer and Allen (1991) found that employee participation in work and decision making is a significant positive predictor of job satisfaction and organizational commitment.

\subsection{Job Satisfaction}

Job satisfaction is frequently used as expressing individual attitude towards a specific job. Social scientists have shown a wide interest to find out the consequences and outcome of job satisfaction. Hence the dynamic nature of the job satisfaction attracted so many researcher and theorist for a sophisticated measurement and theoretical improvement pertaining to job satisfaction. Locke (1976) defined job satisfaction as "a pleasurable or positive emotional state resulting from an appraisal of one's job or job experiences". These are the positive responses to specific aspects of the job and play an important role in improving performance and enhancing employee commitment. Hop Pock (1995) defined employee satisfaction as "any combination of psychological, 
physiological and environmental circumstances that causes the person truthfully to say I am satisfied with my job". Based on such conceptualization, Hulin and Judge (2003) explained job satisfaction as cognitive, affective and behavioral responses to an individual's job.

\section{Review of Literature}

Teachers are the back bone of any nation and play an important role in the nation building. Higher and technical education is a big challenge for the policy makers, thus it is important to have competent and effective teaching system. Thus, success and effectiveness of teaching system is depends upon the quality of its teachers. In this changing scenario of education, it will be interesting to bring out the relationship between HRM practices and job satisfaction.

Numbers of studies suggest that HRM practices have a significant influence on the job satisfaction. Nayak and Nayak (2014) conducted a research on 234 teachers, found that HRM practices like supervision, employee relationship, remuneration growth opportunities and work itself promotion have a significant impact on employee job satisfaction. Hinai and Bajracharya (2014) found in his study that remuneration and development, management support, students, colleagues, workload, and status of job were positively associated with job satisfaction. Work load was the most strongly associated with job satisfaction followed by the perception about colleagues, status of job, management support, and remuneration and development. Khan et al. (2012) found that male faculty members of the university are more satisfied than the female faculty member. HRM practices that are offered by the universities do not satisfy male and female equally. Female teachers are found more satisfied with HR practices than the male faculty members of universities. While comparing public and private universities it is found that faculty member of government universities teachers are more satisfied than private universities. It was also found that there was a direct relationship with the tenure of experience and job satisfaction.

Khalid et. al. (2012) conducted a study on 108 faculty members to investigate the relationship between various facets of job satisfaction among university academicians in Punjab Province, Pakistan. Results of the study indicated that a pay differential does exist between private and public universities in Pakistan. Academicians in private sector universities were more satisfied with their pay, supervision, and promotional opportunities than the academicians of public university. On the other hand, academicians in public sector universities were found more satisfied with co-worker's behavior and job security. Adeel et.al.(2011) investigated the influence of HR practices (compensation practices, employee performance evaluation practices, promotion practices, empowerment practices) in universities on job satisfaction. Result of study described that the teachers were satisfied with job itself, compensation practice and empowerment practice, whereas dissatisfied with promotion practice and performance evaluation practices. Teacher satisfaction is not predicted by these set of HR practices so there are some other factor which effect satisfaction.

The study conducted by $\mathrm{Ch}^{\text {ee }}$ g et al, (2010) shows that management support, salary and promotion opportunities are significant in determining the Job Satisfaction level of College Teachers. Singh (2012) asserted that there is a significant difference in Job Satisfaction among college teachers with regard to gender in self financing institutions. Santhapparaj and Alam (2005) examined the relationships between pay, promotion, fringe benefits, working condition, support of research, support of teaching, gender and job satisfaction of 173 academic staff in private universities in Malaysia. The results indicated that pay, promotion, working condition and support of research have positive and significant effect on job satisfaction. On the other hand fringe benefits and support of teaching have negative effect. Romle (2006) conducted a study on Assistant Registrars working public institutions of higher studies in northern region of Malaysia to find out the relationship of management practices and job satisfaction. It was observed in the results those assistant registrars are satisfied with the HRM practices and have a positive influence on job satisfaction.

Chen et al., (2006) measured the job satisfaction of the 248 teachers in private university in China on the satisfaction determinants, namely organisation vision, respect, result feedback and motivation, management system, pay and benefits, and work environment. The analytical results showed that higher education employees focus on high salaries and fair promotion systems. Investigations of the job satisfaction of college teachers in Europe and America have produced similar results. Sseganga \& Garrett (2005) measured the job satisfaction of academicians among the universities of Uganda by using nine general element of their work comprising research, teaching, remuneration, governance, opportunities for promotion, supervision, working environment co-worker's behavior and the job in general. 


\subsection{Objective of the Study}

1. To study the level of human resource management practices and job satisfaction among the faculty members in the private and public educational institutions.

2. To examine the impact of human resource management practices on job satisfaction.

\section{Research Methodology}

The Investigator decided not to formulate any Hypothesis rather make the study as Exploratory in nature and hence concentrated on objective of the study.

As per the requirement of the research objectives, faculty members from government and self financed educational institutes with more than two years of experiences were used as population. The study was conducted on a sample of 546 faculty members out of which 341 faculty members were from self financed and 205 faculty members were from government educational institutes. But 20 questionnaires were rejected because of various reasons and at last 526 samples were used for the study.

Table 1. Frequency of respondent's type of institution

\begin{tabular}{ll}
\hline Type of Institute & Frequency \\
\hline Government Educational Institute & 194 \\
Self Financed Institute & 332 \\
Total & 526 \\
\hline
\end{tabular}

Table 2. Biographical characteristics of the respondents

\begin{tabular}{|c|c|c|c|c|c|c|c|}
\hline $\begin{array}{l}\text { Government } \\
\text { Institutions }\end{array}$ & Educational & $\begin{array}{l}\text { Self Financed } \\
\text { Institutions }\end{array}$ & Educational & $\begin{array}{l}\text { Government } \\
\text { Institutions }\end{array}$ & Educational & $\begin{array}{l}\text { Self Financed } \\
\text { Institutions }\end{array}$ & Educational \\
\hline Male Faculty & Female & Male Faculty & Female & Low & high & Low & high \\
\hline Members & $\begin{array}{l}\text { Faculty } \\
\text { Members }\end{array}$ & Members & $\begin{array}{l}\text { Faculty } \\
\text { Members }\end{array}$ & Experienced & Experienced & Experienced & Experienced \\
\hline 118 & 76 & 176 & 156 & 78 & 116 & 193 & 139 \\
\hline
\end{tabular}

Faculty member with more than two years of experiences were taken in to consideration. The data were collected using survey method. Each of the respondents was personally contacted and the data was collected through questionnaire. A purposive random sampling were used to collect the data. Respondents were also provided with detailed instructions as to how the questionnaires were to be completed and returned. The rationale behind providing clear instructions and assuring confidentiality of information is based on the fact that this significantly reduces the likelihood of obtaining biased responses.

Qureshi, and Ramay (2006) scale comprised of 25 items, which contained questions on training, team work, performance appraisal, compensation, and employee participation was used to measure HRM Practices. Scale developed by Singh (1989) was used to measure job satisfaction. This scale consists of 20 items that measures the degree of job satisfaction. Each item was rated on five point rating scale ranging from highly satisfied to highly dissatisfied with a weighted score of 5 to 1 , the total score of an individual varies from 20-100. The reliability and validity of the scale is within acceptable norms.

The collected data were tabulated as per the research design to meet out the objectives of the study and suitable statistical tools like Mean, Median, S.D., Correlation and Critical ration (t-Value) were calculated using SPSS.

\section{Results and Discussion}


Table 3. Mean and SD value of the dimensions of human resource management practices and job satisfaction of faculty members of government and self financed educational institution.

\begin{tabular}{lllll}
\hline \multirow{2}{*}{ Components } & \multicolumn{1}{c}{ Golf-financed } & \multicolumn{2}{c}{$\begin{array}{l}\text { educational } \\
\text { institution }\end{array}$} \\
\cline { 2 - 5 } & Mean & S.D & Mean & S.D \\
\hline Training & 14.62 & 3.57 & 14.97 & 3.73 \\
Performance Appraisal & 14.25 & 3.76 & 14.62 & 3.69 \\
Team Work & 15.26 & 3.35 & 15.28 & 3.22 \\
Employee Participation & 13.93 & 3.44 & 14.42 & 3.43 \\
Compensation & 14.33 & 4.23 & 14.54 & 3.47 \\
Total HRM & 72.39 & 13.90 & 73.84 & 12.6 \\
Job Satisfaction & 69.54 & 11.79 & 73.13 & 9.46 \\
\hline
\end{tabular}

It is observed from the table 3 that the faculty member of Government Educational institutes were showing satisfaction to the moderate extent with the overall HRM practices. Employees were more satisfied with training, teamwork and employee participation and satisfied to small extent with performance appraisal and compensations. It is clearly showed that Government Educational institutes offered policies to enhance Training, Teamwork and Employees Participation and moreover employees were also satisfied with these practices. Performance appraisal and compensations practices were not found satisfying among the Government Institute's employees. Contradictory to our belief that government sector is spending lot of money on training, teamwork and employee participation which further can say that the government is not logical in their endeavor. It is found in the study that the faculty member of self financed institutes were showing satisfaction to the moderate level with the overall HRM practices. Employees were more satisfied with team work. While faculty members were satisfied to small extent with Training, Employee participation, Performance appraisal and Compensations.

These results are supported by the finding of Majumder (2012) as HRM dimensions does not satisfy to the employees equally. Most of the employees are dissatisfied with compensation package followed by reward and motivation, career growth, training and development, management style, and job design and responsibilities. HRM practice compensation revealed as most dissatisfied factor among school teachers, hence teachers were not satisfy with their salaries, Steyn and van Wyk (1999) and Olivier and Venter's (2003). Grace and Khalsa (2003) concluded compensation as strong dominant factor for job satisfaction among the faculty members of higher education institution. While on the dimension of job satisfaction faculty members of Government and self financed educational institutes are showing moderately high level of job satisfaction again contradictory to our finding where job satisfaction is high.

Table 4. Mean and SD value of the dimensions of human resource management practices and job satisfaction of male faculty members of government and self financed educational institution

\begin{tabular}{|c|c|c|c|c|}
\hline \multirow[t]{2}{*}{ Components } & \multicolumn{2}{|c|}{ Government Educational institution } & \multirow{2}{*}{$\begin{array}{l}\text { Self-financed } \\
\text { institution } \\
\text { Mean }\end{array}$} & \multirow[t]{2}{*}{ educational } \\
\hline & Mean & S.D & & \\
\hline Training & 15.60 & 3.53 & 14.75 & 2.99 \\
\hline Performance Appraisal & 14.95 & 2.96 & 14.78 & 3.60 \\
\hline Team Work & 15.47 & 2.78 & 15.63 & 3.21 \\
\hline Employee Participation & 16.25 & 2.90 & 13.39 & 3.04 \\
\hline Compensation & 15.01 & 3.71 & 14.69 & 4.07 \\
\hline Total HRM & 77.28 & 12.65 & 73.25 & 11.54 \\
\hline Job Satisfaction & 73.74 & 9.51 & 70.77 & 11.39 \\
\hline
\end{tabular}

Male faculty members of Government Educational institutes were showing high satisfaction with the overall HRM practices. Male faculty members were more satisfied with Training, Teamwork and Employee participation, where as they were satisfied to less extent with performance appraisal and compensations. In case of self financed Institutes, it is investigated that male faculty members were showing satisfaction to the moderate 
extent with the overall HRM practices. Male faculty members were reported satisfied to small extent with training practices, performance appraisal, compensations practices and employee participation, where as they were satisfied to moderate extent with Team work.

Table 5. Mean and SD value of the dimensions of human resource management practices and job satisfaction of female faculty members of government and self financed educational institution

\begin{tabular}{|c|c|c|c|c|}
\hline & \multicolumn{2}{|c|}{ Government Educational institution } & $\begin{array}{l}\text { Self-financed } \\
\text { institution }\end{array}$ & educational \\
\hline Components & Mean & S.D & Mean & S.D \\
\hline Training & 14.66 & 4.38 & 14.07 & 3.81 \\
\hline Performance Appraisal & 13.57 & 3.64 & 13.82 & 4.31 \\
\hline Team Work & 14.47 & 3.55 & 15.10 & 3.59 \\
\hline Employee Participation & 15.03 & 3.27 & 12.73 & 3.43 \\
\hline Compensation & 13.72 & 4.3 & 13.92 & 3.97 \\
\hline Total HRM & 71.45 & 15.52 & 69.64 & 14.38 \\
\hline Job Satisfaction & 69.39 & 12.04 & 68.69 & 11.48 \\
\hline
\end{tabular}

It is observed from the results that female faculty members from the government institutes are less satisfied with training practices, performance appraisal practices, team work and compensations practices. Female faculty member of self financed Institutes were satisfied to below average or dissatisfied with the dimensions of HRM practices like performance appraisal, Employee participation and compensations. Bishay (1996) research supported the results that female teachers were satisfied to less extent with overall HRM practices. Female faculty member were less satisfied with compensation as compare to the male faculty member. Results of the study contradictory to the study of Perie and Baker (1997) reported high level of job satisfaction among female teachers than male teachers.

Table 6. Mean and SD value of the dimensions of human resource management practices and job satisfaction of less experienced faculty members of government and self financed educational institution

\begin{tabular}{|c|c|c|c|c|}
\hline \multirow[t]{2}{*}{ Components } & \multicolumn{2}{|c|}{ Government Educational institution } & \multirow{2}{*}{$\begin{array}{l}\text { Self-financed } \\
\text { institution } \\
\text { Mean }\end{array}$} & \multirow[t]{2}{*}{ educational } \\
\hline & Mean & S.D & & \\
\hline Training & 14.67 & 4.11 & 14.60 & 3.29 \\
\hline Performance Appraisal & 13.96 & 3.3 & 14.38 & 3.96 \\
\hline Team Work & 15.08 & 3.2 & 15.35 & 3.42 \\
\hline Employee Participation & 15.66 & 3.04 & 13.09 & 3.31 \\
\hline Compensation & 14.38 & 4.47 & 14.30 & 4.11 \\
\hline Total HRM & 73.75 & 14.49 & 71.72 & 13.59 \\
\hline Job Satisfaction & 71.05 & 11.12 & 68.81 & 12.05 \\
\hline
\end{tabular}

It is cleared from the results that less experienced faculty members of Government Educational institutes were also less satisfied with Training, performance appraisal and compensations, it means faculty member are required changes in the training programs, faculty members also challenged the performance appraisal parameters to evaluate their performance. Teamwork and employee participation practices were found at moderate level, as they appreciate the initiative of team work and their participation in the decision making. Less experience faculty members of self financed Institutes were less satisfied with training practices with Training, performance appraisal, compensations and employee participation, and to the moderate extent with Team work. Results are in consistent with the study of Perie and Baker (1997) that young and less experienced school teachers working in public school shown high job satisfaction. 
Table 7. Mean and SD value of the dimensions of human resource management practices and job satisfaction of less experienced faculty members of government and self financed educational institution

\begin{tabular}{lllll}
\hline Components & Government Educational institution & \multicolumn{2}{l}{$\begin{array}{l}\text { Self-financed } \\
\text { institution } \\
\text { Mean }\end{array}$} & S.D \\
\hline Training & Mean & S.D & Meational \\
Performance Appraisal & 16.15 & 3.37 & 13.93 & 3.73 \\
Team Work & 15.14 & 3.20 & 14.17 & 4.03 \\
Employee Participation & 15.07 & 3.06 & 15.48 & 3.36 \\
Compensation & 15.96 & 3.20 & 13.06 & 3.05 \\
Total HRM & 14.70 & 3.06 & 14.40 & 3.81 \\
Job Satisfaction & 77.01 & 13.30 & 71.04 & 11.42 \\
\hline
\end{tabular}

It is cleared from the results that high experience faculty members of Government educational institutes were less satisfied with compensations and to the moderate extent with Training, performance appraisal, Teamwork and employee participation. High experienced faculty members on dimension training and compensations, indicating agreement to a small extent and to a moderate extent with performance appraisal, team work and employee participation.

Table 8. T-test analysis of the faculty members of self financed and government educational institutions on the dimensions of the human resources management practices and job satisfaction

\begin{tabular}{|c|c|c|c|c|c|}
\hline Components & Sector & $\mathrm{N}$ & Mean & $\mathrm{SD}$ & $\mathrm{T}-$ test \\
\hline \multirow[t]{2}{*}{ Training } & Govt & 194 & 14.62 & 3.576 & 0.999 \\
\hline & Private & 332 & 14.97 & 3.730 & \\
\hline \multirow[t]{2}{*}{ Performance Appraisal } & Govt & 194 & 14.25 & 3.764 & 1.053 \\
\hline & Private & 332 & 14.62 & 3.693 & \\
\hline \multirow[t]{2}{*}{ Team Work } & Govt & 194 & 15.26 & 3.351 & 0.065 \\
\hline & Private & 332 & 15.28 & 3.224 & \\
\hline \multirow[t]{2}{*}{ Employee Participation } & Govt & 194 & 13.93 & 3.446 & 1.499 \\
\hline & Private & 332 & 14.42 & 3.439 & \\
\hline \multirow[t]{2}{*}{ Compensation } & Govt & 194 & 14.33 & 4.233 & 0.568 \\
\hline & Private & 332 & 14.54 & 3.476 & \\
\hline \multirow[t]{2}{*}{ Total HRM } & Govt & 194 & 72.39 & 13.909 & 1.224 \\
\hline & Private & 332 & 73.84 & 12.660 & \\
\hline \multirow[t]{2}{*}{ Job Satisfaction } & Govt & 194 & 69.54 & 11.790 & $3.383^{*}$ \\
\hline & Private & 332 & 73.13 & 9.462 & \\
\hline
\end{tabular}

In table 8, t-test analysis was conducted for the significant differences of human resources management practices and job satisfaction among the faculty members of self financed and government institutes. For the all dimensions and HRM as p values was observed more than 0.05 . This signifies that there was no significant difference between the government and private faculty's scores on all HRM practices and job satisfaction.

Table 9. Showing the correlation between the HRM practices and job satisfaction among the faculty members of government and self financed educational institutions

\begin{tabular}{|c|c|c|c|c|c|c|c|c|c|c|}
\hline \multirow[t]{2}{*}{ Components } & $\begin{array}{l}\text { Job Sat } \\
\text { Faculty }\end{array}$ & & \multicolumn{2}{|c|}{ Male Faculty Members } & $\begin{array}{l}\text { Female } \\
\text { Members }\end{array}$ & Faculty & $\begin{array}{l}\text { Low } \\
\text { Faculty }\end{array}$ & $\begin{array}{l}\text { Experienced } \\
\text { embers }\end{array}$ & $\begin{array}{l}\text { d High } \\
\text { Faculty } \\
\text { Govt }\end{array}$ & $\begin{array}{l}\text { Experienced } \\
\text { embers }\end{array}$ \\
\hline & $\overline{\text { Govt }}$ & $\begin{array}{l}\text { Self } \\
\text { Financed }\end{array}$ & Govt & $\begin{array}{l}\text { Self } \\
\text { Financed }\end{array}$ & Govt & $\begin{array}{l}\text { Self } \\
\text { Financed }\end{array}$ & Govt & $\begin{array}{l}\text { Self } \\
\text { Financed }\end{array}$ & Govt & $\begin{array}{l}\text { Self } \\
\text { Financed }\end{array}$ \\
\hline Training & $.430^{* *}$ & $.119^{*}$ & $.220^{*}$ & .050 & $.614^{* *}$ & $.165^{*}$ & $.445^{* *}$ & .088 & $.359^{* *}$ & $.300^{* *}$ \\
\hline $\begin{array}{l}\text { Performance } \\
\text { Appraisal }\end{array}$ & $.353^{* *}$ & $.332^{* *}$ & $.258^{* *}$ & $.356^{* *}$ & $.394^{* *}$ & $.298^{* *}$ & $.278^{* *}$ & $.309^{* *}$ & $.456^{* *}$ & $.469^{* *}$ \\
\hline Team Work & $.256^{* *}$ & $.310^{* *}$ & $.206^{*}$ & $.332^{* *}$ & $.257^{*}$ & $.280^{* *}$ & .135 & $.341^{* *}$ & $.491^{* *}$ & .200 \\
\hline $\begin{array}{l}\text { Employee } \\
\text { Participation }\end{array}$ & $.445^{* *}$ & $.376^{* *}$ & $.278^{* *}$ & $.339^{* *}$ & $.583^{* *}$ & $.403^{* *}$ & $.428^{* *}$ & $.357^{* *}$ & $.472^{* *}$ & $.493^{* *}$ \\
\hline Compensation & $.366^{* *}$ & $.534^{* *}$ & $.230^{*}$ & $.483^{* *}$ & $.469^{* *}$ & $.584^{* *}$ & $.320^{* *}$ & $.527^{* *}$ & $.490^{* *}$ & $.600^{* *}$ \\
\hline Total HRM & $.460^{* *}$ & $.472^{* *}$ & $.299^{* *}$ & $.476^{* *}$ & $.578^{* *}$ & $.461^{* *}$ & $.408^{* *}$ & $.444^{* *}$ & $.541^{* *}$ & $.655^{* *}$ \\
\hline
\end{tabular}


In case of government institutes, a significant positive correlation has obtained among the Job Satisfaction with the dimensions of the human resources management. It means job satisfaction is positively linked with HRM practices. Positive enhancement is observed in Job satisfaction with the increase efforts in the HRM dimensions. The analysis was in consistent with the Hasan et al. (2013) study showed that there was a significant positive relation between employee compensation and appraisal system with employee satisfaction. Human resource management practices are closely linked with job satisfaction. It is believed and proved by many researchers that effective implementation of human resource practices improve the level of job satisfaction positively. Edgar and Geare (2005) and Yu and Egri (2005), also found that human resource management practices has positive impact on job satisfaction. The result of the study also supported by study of Sarker and Afroze (2014) indicated that HRM practices have significant influence on job satisfaction. Uddin and Rahman (2014) supported the study as employee job satisfaction was comparatively more positively associated with promotional opportunity and benefits. In case of self financed institutes, significant positive correlation was found among the Job Satisfaction and the various dimensions of the human resources management practices. Compensation found to have positive impact on job satisfaction. It means with the increase in compensation practices or improved compensation practices will increase the level of job satisfaction among the faculty members.

\section{Conclusion}

On the bases of above finding it is concluded that faculty member of government educational institutes has a moderate level of satisfaction with the overall HRM practices. Employees were more satisfied with training, teamwork and employee participation and satisfied to small extent with performance appraisal and compensations. Faculty member of self financed institutes were also shown moderate level of satisfaction with the overall HRM practices. Employees were more satisfied with team work and satisfied to small extent with training, employee participation, performance appraisal and compensations. The study also revealed that there is no significant difference between the government and private educational institution's faculty scores on all HRM practices. A significant positive correlation has been obtained among the job satisfaction with the dimensions of the human resources management in both government and private educational institution's faculty members.

\section{References}

Adeel, M., Khan, I., Danial, A. H., \& Ahmad, B. (2011). Impact of HR practices on job satisfaction of university teacher: Evidence from universities in Pakistan. Industrial Engineering Letters, 1(3), 10-17.

Armstrong, M. (2001). A Handbook of Human Resource Practice (8th ed.). Kogan Page, London.

Bishay, A. (1996). Teacher motivation and job satisfaction: A study employing the experience sampling method. Journal of Undergraduate Sciences, 3, 147-154.

Chng, H. K., Chong, W. K., \& Nake. (2010). The Satisfaction Level of Penang Private Colleges Lecturers. International Journal of Trade, Economics and Finance, 1(2). https://doi.org/10.7763/IJTEF.2010.V1.30

Chen, S. H., Yang, C. C., Shiau, J. Y., \& Wang, H. H. (2006). The development of an employee satisfaction model for higher education. TQM Mag, 18(5), 484-500. https://doi.org/10.1108/09544780610685467

Edgar, F., \& Geare, A. (2005). HRM practice and employee attitudes: Different measure s- different results. Personnel Review, 34(5), 534-549. https://doi.org/10.1108/00483480510612503

Grace, D. H., \& Khalsa, S. A. (2003). Re-recruiting faculty and staff: The antidote to today's high attrition. Independent School, 62(3), 20-27.

Hassan, M., Hassan, S., Khan, A., \& Iqbal, A. (2013). Impact of HR Practices on Employee Satisfaction and Employee Loyalty: An Empirical Study of Government Owned Public Sector Banks of Pakistan. Middle-East Journal of Scientific Research, 16(1).

Hinai, Z. A., \& Bajracharya, A. (2014). A Study on the Factors Affecting Job Satisfaction of Academic Staff in Higher Education Institution. 13th International Academic Conference, International Institute of Social and Economic Sciences, Antibes.

Hoppock, R. (1995). Job satisfaction, Harper and Brothers. New York, NY.

Hulin, C. L., \& Judge, T. A. (2003). Job attitudes, Hand book of psychology Industrial and organizational psychology. Hoboken, NJ: Wiley.

Huselid, M. A. (1995). The impact of human resource management practices on turnover, productivity and corporate financial performance. Academy of Management Journal, 38(3), 635-672. https://doi.org/10.2307/256741 
Khalid, S., Irshad, M. Z., \& Mahmood, B. (2012). Job satisfaction among academic staff: a comparative analysis between public and private sector universities of Punjab, Pakistan. International Journal of Business and Management, 7(1), 126-136.

Khan, I., Ghauri, T. A., Akram, K. (2012). Relationship between Job Satisfaction and HR Practices, an Empirical Research of Different Sectors of University Teachers in Pakistan. International Journal of Learning and Development, 2(3), 25-33. https://doi.org/10.5296/ijld.v2i3.1756

Koch, M. J., \& McGrath, R. G. (1996). Improving labour productivity: human resource management policies do $\begin{array}{lllll}\text { matter. Strategic } & \text { Management 335-354. }\end{array}$ https://doi.org/10.1002/(SICI)1097-0266(199605)17:5<335::AID-SMJ814>3.0.CO;2-R

Locke, E. A. (1976). The nature and causes of job satisfaction. In M. D. Dunnette (Ed.), Handbook of industrial and organizational psychology (pp. 1297-1343).

Luthans, F. (1998). Organisational Behaviour (8th ed.). Boston: Irwin McGraw-Hill.

Majumder, T. H. (2012). Human Resource Management Practices and Employees' Satisfaction towards Private Banking Sector in Bangladesh. International Review of Management and Marketing, 2(1), 52-58.

Meyer, J. P., \& Allen, N. J. (1991). A three-component conceptualization of organizational commitment. Human Resources Management Review, 1(1), 61-89. https://doi.org/10.1016/1053-4822(91)90011-Z

Nayak , N., \& Nayak, M. (2014). A Study Job Satisfaction Among University Teachers in India. The Clute Institute International Academic Conference Orlando, Florida, USA.

Olivier, M. A. J., \& Venter, D. J. L. (2003). The extent and causes of stress in teachers in the George region. South African Journal of Education, 23(3), 186-192.

Perie, M., \& Baker, D. (1997). Job satisfaction among America's teachers: Effects of workplace conditions, background characteristics and teacher compensation. Washington: National Centre for Statistics.

Pfeffer, J. (1994). Competitive Advantage through People. Boston, M A: Harvard Business School Press.

Poole, M., \& Jenkins, G. (1997). Responsibilities for Human Resource Management practices in the modern enterprise. Personnel Review, 26(5), 333-56. https://doi.org/10.1108/00483489710176039

Qureshi, M. T., \& Ramay, I. M. (2006). Impact of Human Resource Management Practices on Organizational Performance in Pakistan. Muhammad Ali Jinnah University Islamabad.

Redman, T., \& Mathews, P. B. (1998). Service quality and human resource management: A review and research agendas. Personnel Review, 27(1), 57-77. https://doi.org/10.1108/00483489810368558

Romle, A. R., \& Shamshudin, A. S. (2006). The Relationship between Management Practices and Job Satisfaction: The Case of Assistant Registrars at Public Institutions of Higher Learning in Northern Region Malaysia. The Journal of Human Resource and Adult Learning, 72-80.

Salas, E., Dickinson, T., Converse, S., \& Tannenbaum, S. (1992). Towards an understanding of team performance and training.

Santhapparaj, A. S., \& Alam, S. S. (2015). Job Satisfaction Among Academic Staff in Private Universities in Malaysia. Journal of Social Sciences, 1(2), 72-76.

Sarker, A. R.., \& Afroze, R. (2014). Can HRM Practices Improve Job Satisfaction of Ready Made Garment (RMG) Workers in Bangladesh? An Alternative Solution to Recent Unrest. International Journal of Business and Management, 9(10). https://doi.org/10.5539/ijbm.v9n10p185

Schuler, R. S., \& Jackson, S. E. (1987). Linking competitive strategies with human resource management practices. Academy of Management Executive, 1(3), 207-219. https://doi.org/10.5465/AME.1987.4275740

Singh, S. (1989). Organizational stress, Job Satisfaction and executive behaviour. Unpublished Research Monograph. Sri Ram Centre for Industrial Relations and human Resources, New Delhi.

Singh, Y. G. (2012). Job Satisfaction of Teacher-Educator working in Self Finance Teacher Educational Institutions. International Indexed \& Refereed Journal, 3(30).

Sseganga, K., \& Garrett, R. M. (2005). Job satisfaction of university academics: Perspectives from Uganda. Higher Education, 50, 33-56. https://doi.org/10.1007/s10734-004-6346-0

Steyn, G. M., \& Van Wyk, J. N. (1999). Job satisfaction: Perceptions of principals and teachers in urban black schools in South Africa. South African Journal of Education, 19(1), 37-43. 
Tambe, M. (1997). Towards flexible teamwork. Journal of AI Research.

Uddin, M. M., \& Rahman, M. (2014). Measurement of Employees Job Satisfaction on HRM Practices of Commercial Banks in Bangladesh. Proceedings of 11th Asian Business Research Conference, BIAM Foundation, Dhaka, Bangladesh.

Yu, B. B., \& Egri, C. P. (2005). Human resource management practices and affective organizational commitment: A comparison of Chinese employees in a state-owned enterprise and a joint venture. Asia Pacific Journal of Human Resources, 43(3), 332-360. https://doi.org/10.1177/1038411105058706

\section{Copyrights}

Copyright for this article is retained by the author(s), with first publication rights granted to the journal.

This is an open-access article distributed under the terms and conditions of the Creative Commons Attribution license (http://creativecommons.org/licenses/by/4.0/). 